First publ. in: International Interactions : Empirical and Theoretical Research in International Relations ; 38 (2012), 4. - pp. 443-461

\title{
The Dynamics of Mass Killings: Testing Time-Series Models of One-Sided Violence in the Bosnian Civil War
}

\author{
GERALD SCHNEIDER \\ University of Konstanz \\ MARGIT BUSSMANN \\ University of Greifswald \\ CONSTANTIN RUHE \\ University of Konstanz
}

\begin{abstract}
Many observers contend that wartime civilian victimization is an instrument of political leaders to achieve a particular goal. This article examines whether retaliation for similar acts by the other side, the developments on the battlefield, or the behavior of international actors accounts for the ups and downs of this so-called one-sided violence. Using information from the Konstanz One-Sided Violence Event Dataset and other sources, we evaluate the empirical relevance of these complementary models statistically. Time series analyses of the weekly number of killed and harmed Muslims (Bosniacs) and Serbs during the Bosnian civil war support the military and the massacre logic. We show that the Serbian side decreased one-sided violence following a territorial conquest, but that its one-sided violence was not a reciprocal response to the Bosniac targeting of civilians. Conversely, the Bosniac side resorted to violence during times of increasing Serbian atrocities and when the fighting was particularly intense. The analysis reveals that most international interventions did not reduce the carnage, but that the Serbs responded to Russian moves.
\end{abstract}

\footnotetext{
We would like to thank Alexander Downes, Michael Colaresi, Sonja Grimm, Lisa Groß, and two reviewers for helpful comments; the German Foundation for Peace Research for financial support: and Vanessa Dinter for assistance. Replication material is available at http://dvn.iq.harvard.edu/dvn/dv/ internationalinteractions/ and the homepage of the first author, http://www.polver.uni-konstanz.de/en/ gschneider/working-papers/replication-data/.

Address correspondence to Gerald Schneider, University of Konstanz, Department of Politics and Public Administration, Box 86, 78457 Konstanz, Germany. E-mail: gerald. schneider@uni-konstanz.de
} 
KEYWORDS ARIMA models, Bosnia, civil war, civilian victimization (one-sided violence), vector autoregression

Recent evidence has convincingly established that the harming and killing of civilians during warfare largely follows a strategic logic (for example, Downes 2008; Kalyvas 2006). The findings that civilian victimization is not a random act have been mainly based on cross-sectional or descriptive research designs. This article adds a dynamic perspective to this literature. It examines, with the help of time series regression, the ups and downs in the number of unarmed civilians the Serbs and the Bosniacs targeted during the Bosnian civil war.

The statistical examination assesses the empirical relevance of three causal mechanisms that are repeatedly referred to account for the changing severity that characterizes these lethal acts. The massacre logic contends that one-sided violence is planned and that the targeted group resorts to retaliation for the civilian victimization it had to endure in previous periods. Similarly, the military logic conceives one-sided violence as a means which the warring parties employ in order to influence the situation on the battleground. The theory of asymmetric warfare suggests that the weaker side relies on massacres to counteract its lack of military power. Some recent empirical studies, conversely, imply that the winning group may use onesided violence as a complement to its military campaign and as an instrument to change the strategic balance more permanently following a momentary success on the ground. The international logic that we develop distinguishes between different levels of severity of actions that the international community takes against the massacres. We expect that UN resolutions calling for "hard" sanctions and military interventions rather than the shaming of the perpetrator through public condemnations are able to reduce the lethality of the mass-murdering acts.

We examine the explanatory power of these complementary rather than competitive models through an examination of event data of the civil war in Bosnia-Herzegovina. Our analysis makes use of the Konstanz One-Sided Violence Event Dataset (KOSVED) to analyze the weekly number of civilians killed or harmed through acts of one-sided violence. According to the KOSVED definition, one-sided violence consists of acts perpetrated by an organized group, which can either be a rebel organization or government troops, against unarmed noncombatants resulting in the immediate physical harming or death of these victims (Schneider and Bussmann 2012). ${ }^{1}$

\footnotetext{
${ }^{1}$ For similar definitions see Eck and Hultman (2007) or Downes (2008). Note that Downes (2008:14) reduces "civilian victimization" to a "government-sanctioned military strategy." Rummel's (1994:1) notion of "democides" is, by contrast, more encompassing and also covers genocides and mass-murders by "self-governing groups."
} 
In the Bosnian case, all major groups resorted to this form of violence. Our examination refers, in a directed dyad analysis, to the acts perpetrated by the most violent groups, the Serbs and the Bosniacs. According to our most conservative estimate, the Serbs were responsible for about 21,458 civilian victims and the Bosnian Muslims for around 1,683 within this dyad. Autoregressive Integrated Moving Average (ARIMA) and Vector Autoregression (VAR) models support the thesis that one-sided violence follows a strategic logic. We find evidence for all three explanatory models and are able to demonstrate that a growing number of battles increase the number of civilian victims. The analyses only partially support the argument that the winners in these military encounters kill or harm more innocent bystanders than the losers. Our dynamic models reveal that past one-sided violence bears heavily on the risk of experiencing further immediate civilian victimization. More technically, this instrument of violence is highly autoregressive and therefore hard to suppress once it is unleashed. International variables only exert a limited influence, indicating that third parties better act preventively rather than becoming involved at the moment where the civilian victimization has already set in.

\section{THE DYNAMICS OF ONE-SIDED VIOLENCE: THREE MODELS}

Civil war scholars are still divided on what explains the occurrence of violent acts targeted at unarmed civilians (Schneider, Banholzer, and Haer 2011). Most researchers, however, agree that at least the mass killings are intentional and often guided by the strategic interests of the contending groups. Kalyvas' (1999, 2006) research on acts of one-sided violence in Algeria and Greece shows in this line that violent acts against civilians "are likely to be committed by insurgents in the context of a particular strategic conjuncture" (1999:245). This article starts from a similar premise and assumes that most instances of one-sided violence are planned, ordered, and executed with a specific purpose. We adopt an instrumental view of this form of political violence and examine the conditions under which it evolves over time within one particular civil war.

The literature suggests different, but not mutually exclusive strategic logics behind the acts of one-sided violence. Concepts like "ethnic cleansing," for instance, indicate that one-sided violence can have genocidal traits aimed at a particular group because of ethnic or political differences (Kuper 1982), while others study massacres more as a part of developments on the battlefield (for example, Downes 2008). We will elaborate on these explanations below and compare them with the conditions under which international interventions are able to stop, or at least to dampen, the level of civilian victimization. 


\section{Massacre Logic}

Many factors that government and rebel leaders presumably take into account when deciding to attack civilians do not change quickly. However, there is a substantial body of literature which suggests that temporality and conflict dynamics matter. To start with, rivalry research demonstrates that states with a history of conflictive relations are more likely to experience a renewed outbreak of armed conflict, a regularity that might be based on learning and adaptation (for example, Crescenzi 2007). Similarly, studies on civil war demonstrate that countries with a longer history of peace are less at risk to experience domestic armed conflict (for example, Hegre and Sambanis 2006).

Temporality also matters in the usage of violence against civilians. For example, genocides and political mass murders are planned events that require sequencing in their execution. The most radical plan to exterminate a specific group is still the Final Solution decided at the Wannsee conference in 1942 with the implicit consent of Hitler (for example, Longerich 1998). The prosecutors of the International Criminal Tribunal of the Former Yugoslavia (ICTY) also explicitly mentioned the genocidal plans of the Serbian leadership in the charges against Slobodan Milošević, Radovan Karadžić, and other key figures responsible for the Bosnian civil war (ICTY 2002, 2009). Even if perpetrators are not following a farsighted scheme like these war criminals, they might adapt their strategies accordingly after an initial mass killing.

A rich historical literature accounts for the "culture" of mass killings that culminated in the then unprecedented death toll of World War I (Kramer 2007). Actors who previously decided that the use of violence against the civilian population might be beneficial to their overall goal, or who were not constrained in the recent past to do so, are more likely to use one-sided violence in current or future time periods. Empirically, we should thus expect that the dynamics of mass killings in civil wars are largely structured by an auto-regressive process. This expresses that one massacre begets another one due to the planning of the perpetrators. Obviously, the possible autoregressive nature of one-sided violence also indicates that such plans are of a relatively short-term nature as periods with less pronounced victimization trigger similarly calm phases, too. The assumed temporal dependence nevertheless means that the usage of one-sided violence is a clear strategy and that the political and military leadership generally accepts this terror instrument to pursue its goals.

H1: The more intensive the one-sided violence by one group directed against another group has been in one period, the more intensive will be these acts in subsequent periods.

As long as the targeted group has the possibility to react, retaliation and revenge are viable options. Event data analyses have established quite 
strongly that reciprocity is one of the pervasive empirical patterns in interstate relations (for example, Schneider, Widmer, and Ruloff 1993). Morrow (2007) offers evidence that interstate one-sided violence follows the logic of reciprocity. According to his analysis, noncompliance with the Laws of War has been met throughout the twentieth century "with some major violations by the side that suffers the consequences of that noncompliance" (2007:570).

Goldstein and Pevehouse (1997) find in a study of the Bosnian civil war evidence for direct and inverse reciprocity. The Serbs, for instance, relied on the latter strategy, dubbed "bullying," when they cooperated with the Bosniacs after the punishments they had received from NATO. Weidmann (2011) shows that violence was more likely in ethnically polarized regions of Bosnia, which suggests at least some reciprocal behavior. One element that helped elites to manipulate soldiers into the usage of violence was a history of intergroup violence (for example, Oberschall 2000).

If one or both actors do not intend to govern the opponent's population, reciprocal extermination is a form of violence that could be found in the context of international but also civil wars. In this case, the conflict party has no interest in securing the support of the opponent's civilian population and might even consider it to be a potential future threat. Instead, the strategy is to use violence to drive the civilians away from the territory and even to use mass deportation to secure an area (Downes 2008; Kalyvas 2006). If the other side responds in kind to these maneuvers, we should observe reciprocated one-sided violence.

H2: The more lethal the one-sided violence of one group directed against another one, the more extreme are the one-sided violence counterreactions.

\section{Military Logic}

The Clausewitzian literature on war as a bargaining process suggests that the ups and downs on the battlefield reflect shifting resource endowments and the beliefs the warring parties have about them (for example, Powell 2002). Especially within an internal war, the civilian support for the warring groups is a key aspect of this continuous strategic exchange. The military logic that we derive from this literature is instrumentalist. It suggests that battle forces, whether belonging to the government or rebel side, become increasingly desperate to prevail and to reduce their losses by intentionally targeting the enemy's support base (Downes 2008). The by-product of this civilian targeting is that it not only reduces the support base of the opponent but that it may also coerce a possibly defiant population to support the murderous faction. As Grossman (1995:207) puts it, "one of the most and obvious and blatant benefits of atrocity is that it quite simply scares the hell 
out of people." In other words, the harming and killing of civilians can bully survivors into compliance or avert them from defection.

It remains, however, largely unclear whether the strong or the weak on the battleground resort to one-sided violence. Valentino, Huth, and BalchLindsay (2004), on the one hand, contend that governments resort to this instrument if they cannot beat insurgents that rely on a hit-and-run strategy with conventional military tactics. Other researchers argue, on the other hand, that rebels target civilians as a weapon of last resort. According to Hultman (2009:833), the Resistência Nacional Moçambicana (RENAMO) carried out massacres "against government constituents with the instrumental aim of making the country ungovernable and forcing the government into concessions by raising the costs for continuing the war."

In many conflicts, one-sided violence goes hand in hand with developments on the battle field. Downes (2008) argues, for example, that the drive for territorial conquest is a reason why conflict parties use violence against civilians. One-sided violence can be an intentionally adopted strategy not just in case of wars of territorial expansions but also if various ethnic groups make demands on the same territory. Killing or expelling the opponent's support base also eliminates the threat of future rebellions in the conquered territory. In other words, targeting civilians is an instrument to terrorize the support base of the losing group, yet it also reflects the desire to preempt a possible challenge by the adversary. Herreros and Criado (2009:440) describe the violence perpetrated by Franco's Falangists during the Spanish civil as "the elimination of would-be political entrepreneurs."

The civil war in Bosnia indicates that the notorious "ethnic cleansing" campaign of the Serbs went hand in hand with developments on the battleground. According to Kalyvas and Sambanis (2005:13), "[o]nce control was achieved, local non-Serbs met various fates. Some were killed immediately, some were imprisoned, and others were harassed, tortured, or forcibly deported." Especially men were executed or sent to detention camps (Burg and Shoup 1999), while massive rape was used against women (Wood 2006:310-313). Hence, one would expect that the Serbian side resorted to one-sided violence during or immediately after the periods when they were successful on the battlefield. A number of examples demonstrate, however, that the Serbs used extensive violence against civilians during sieges. This was for instance the case in Sarajevo and Goražde where the Serbs used heavy shelling and snipers to wear down the Bosnian inhabitants and the troops defending them before they advanced militarily (Burg and Shoup 1999). In this event, most civilian casualties can be expected before the battles are fought and territorial gains are made.

H3: Perpetrators commit fewer acts of one-sided violence during or in the immediate aftermath of territorial conquests. 
Civilian victimization might not always be purely intentional. Schneider and Bussmann (2012) distinguish in this vein between first- and secondorder one-sided violence. While the first category stands for the targeting of civilians as the primary strategy, the latter considers the possibility that political groups commit such acts as a sort of intentional, or at least admissible, collateral damage within a military operation. The Serbian shelling attacks are examples of second-order one-sided violence where the killing and harming of civilians was a deliberate side-product of the military operations (cf. Kaser 2007:410). Empirically, it is difficult to disentangle whether a killing of civilians during conventional military exchanges is intentional. Indeed, there is ample evidence to suggest that the level of civilian abuse increases in most conflicts when the fighting is particularly intensive. Onesided violence occurs primarily within the context of armed conflicts (Eck and Hultman 2007). This renders the battle dynamics in general one of the potential causes - or, some might argue, attributes - of one-sided violence. Therefore, we do not only test the relationship between winning a battle and the initiation of one-sided violence, but also whether the intensity of fighting has an effect.

H4: The number of battles increases the use of one-sided violence.

\section{International Logic}

The weaker side in an internal war often counts on international interventions to change course on the battlefield or to offer protection to its civilian supporters. However, recent studies nurture the pessimism that various instruments used by the international community are only limitedly able to prevent or at least reduce the killing and maiming of the unarmed. In a systematic examination of international interventions and the severity of genocides, Krain (2005) finds that only partisan military interventions reduce the brutality. The Bosnian case seems to support this view as the United Nations Protection Force (UNPROFOR) remained largely impotent when the Serbs continued the shelling or siege of areas that it had declared to be "safe."

The establishment of the ICTY in 1993 was intended to contribute to reconciliation in post-conflict societies but also to prevent future crimes and thus to deter the belligerents from using force indiscriminately. However, Meernik (2005) shows that the effect of arrests and surrenders as well as the ICTY judgments of individual war criminals after the Bosnian conflict on societal peace was negligible. The track record of other international actors during the war was not much better. Describing the inability of the International Committee of the Red Cross in stopping the slaughtering in Srebrenica, Forsythe (2005:115) writes "of the limits of its neutral humanitarianism." 
These results suggest that the effectiveness of the involvement of the international community might vary by type and actor. This expectation finds some support in the event study analysis of Goldstein and Pevehouse (1997). They established that only actions by NATO and the United States influenced Serbian behavior systematically, while the European Union remained largely impotent. This became especially clear in the last phase of the conflict when the armed intervention finally brought the contending forces to the negotiation table in Dayton.

We will also examine whether the conflict parties reacted differently to the various outside interventions. This should be especially the case for some international actions on behalf of the Bosniacs, which culminated in the NATO bombing of Serb forces. We contend that such partial interventions might force the attacked side to reduce the violence against the enemy civilians, but simultaneously leave the level of the equivalent acts by the other side unchanged. At the worst, partial interventions create a window of opportunity to commit additional one-sided violence as one believes to profit from the limited attention the international community devotes to the military forces acting on behalf of the mainly victimised population.

\section{H5: Increased pressure by the international community against one partic- ular conflict party reduces the level of one-sided violence committed by this actor, but increases civilian victimization by the other side.}

\section{RESEARCH DESIGN}

In order to test these conjectures, we rely on three event data sets and some additional information. As we examine the logarithmized weekly number of Bosniacs and Serbs harmed and killed by the adversary, we resort to the KOSVED (Schneider and Bussmann 2012). As taking the logarithm creates missing values for periods without victims of one-sided violence, we assigned a value of 0 to these weeks. ${ }^{2}$ The one-sided violence data is used as an outcome variable for the tests of all hypotheses. As we examine dyadic violence, we had to exclude events without a clearly identified perpetrator or without precise information on the identity of the victims from our analysis. According to the KOSVED data assembled by Dinter (2008), the Serbs were responsible for the killing and harming of more than 21,458 Bosniac victims and the Bosniacs for 1,683 Bosnian Serbs. The analysis excludes the Croatian acts of one-sided violence and the violence directed against Croats that could be observed at the early stage of this

${ }^{2}$ Obviously, the dependent variables-weekly number of killed Serbian or Bosnian Muslim civilians by the other side-are count data. However, weeks with extreme events like Srebrenica rendered the usage of time series count data algorithms inefficient. 
conflict as this short time series does not allow us to test the hypotheses convincingly. Note that our figures are often much more conservative than the ones obtained through surveys (for example, Obermeyer, Murray, and Gakidou 2008; for a critical response see Spagat, Mack, Cooper, and Kreutz 2009) or through archival and census data (for example, Tabeau and Bijak 2005). An illustrative case is the Srebrenica massacre for which KOSVED lists 6,000 victims, but for which a comprehensive report later established a death toll of "at least 7,475" (Brunborg, Lyngstad, and Urdal 2003). The main reason for such discrepancies is our reliance on contemporary media sources. We contend that using these resources is adequate as the warring parties do often not possess much better information than the one that is immediately available to them through public media (Schneider and Bussmann 2012). Thus, the conflict parties as well as the international actors had to base their next steps on this type of information. ${ }^{3}$

We use the Armed Conflict Location and Events Data (ACLED; Raleigh, Linke, Hegre, and Carlsen 2010) to test the hypotheses associated with the military logic, including the number of territorial conquests per week and the number of battles as explanatory constructs. The third data resource used is the Penn State Event Data Project (formerly Kansas Event Data System) to derive information on whether or not an international actor (the European Union, Russia, the United Nations, and the United States) engaged into negotiations with one of the conflicting parties or agreed with the Serbs or Bosniacs in a given week. To estimate the impact of different types of events, we have included the weeks with a NATO attack as a dummy variable and also the number of United Nations resolutions on Bosnia-Herzegovina per week. These resolutions are categorised as to whether the resolution calls for sanctions, enunciates a condemnation, or is related to UNPROFOR or to the ICTY.

We rely on ARIMA and VAR models to test our hypotheses. The former approach allows us to uncover the direction of a particular relationship. The Web appendix details the modelling of the noise component which we abbreviate through the ARIMA formula ( $\mathrm{p}, \mathrm{d}, \mathrm{q}$ ), where $\mathrm{p}, \mathrm{d}$, and q stand for the order of the autoregressive, integrated, and moving average components of the model. ${ }^{4}$ Vector autoregression models are a flexible tool to examine how changes in one series precede changes in another series and in this sense, to use the technical term, "Granger-cause" them. To this end, the approach models each variable as a function of its past realizations and past manifestations of other variables. We will use the VAR models as robustness checks for the ARIMA findings and as a means to test for Granger causality. ${ }^{5}$

\footnotetext{
${ }^{3}$ Dinter's (2008) collection includes a few events listed by the U.S. State Department and Human Rights Watch.

${ }^{4}$ Note that one model includes seasonal components; these model parts are included as P, D, and Q in the abbreviated ARIMA terminology.

${ }^{5}$ The Weh appendix details the model construction and presents alternative specifications. We also discuss the technical literature and justify our model building strategy.
} 


\section{RESULTS}

Before evaluating the empirical relevance of the hypotheses, we indicate with Figure 1 how the patterns of one-sided violence have evolved over 187 conflict weeks. It is clearly visible that one-sided violence has frequently occurred during the Bosnian civil war. However, massacres of an immense
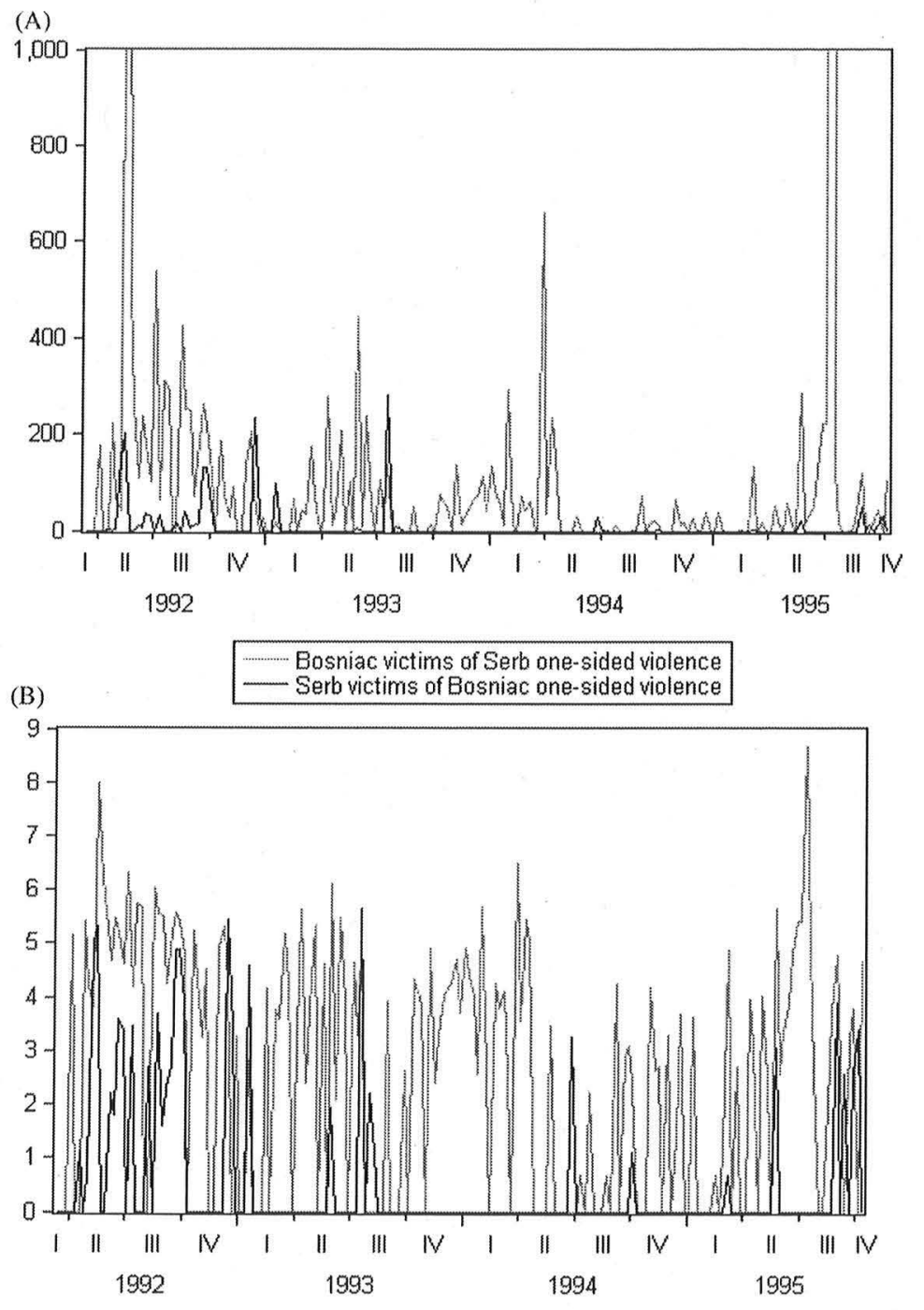

Bosniac victims of Serb one-sided violence (log) Serb victims of Bosniac one-sided violence (log)

FIGURE 1 One-sided violence in the Bosnian civil war: (A) The number of civilian victims among the conflict parties; (B) the number of civilians killed and harmed by perpetrator. All time series are represented through natural logs. 
scope, like the one of Srebrenica, are rare, but in their monstrosity shocking and hard to predict. The graphical evidence furthermore suggests that this sort of violence often seems to come in clusters so that periods of relative calm follow phases of massive civilian suffering and vice versa (Figure 1A). Figure 1B furthermore confirms that the Serbian side was responsible for most of the violence, but that the other warring side also participated in the targeting of the unarmed, although to a much smaller extent. The most extreme weeks on the Serbian side were from July 9 to July 15, 1995, which saw the massacre of Srebrenica, and from May 17 to May 23, 1992, which included the main acts of ethnic cleansing around Prijedor.

We restrict the analysis, as indicated, to the violence perpetrated by the Bosniacs and the Bosnian Serbs. Table 1 offers an examination of what we call the "massacre" and the "military" logics. In accordance with our first hypothesis, there are strong autoregressive tendencies of one-sided violence. This means that weeks with many victims are followed by similarly violent periods, while calm periods prolong themselves to some extent. The first two models show that both sides reciprocate the one-sided violence of the other warring party, but that this mainly takes place in the same week, i.e., Bosniacs were more likely to kill or harm Serbs when Serb violence against Bosniacs increased. This is a first indication that retaliation may account for some attacks on civilians although it is impossible to establish causality in these contemporaneous relationships. In some cases, civilian victimization created a cycle of violence. The International Tribunal (2006), for instance, writes that one victim was "routinely maltreated during the day and at nighttime with various objects, including sticks, knives, and rifle butts... . One of [the assailants] appeared to beat ... in revenge for treatment suffered by him while detained by Bosnian Serbs in Bratunac." The municipality of Skelani offers another sad illustration. Muslims were expelled after the town was taken by Serbian forces. Later a counterattack in the same town was accompanied by the killing of many Serbian civilians fleeing over a bridge, and the Serbs in return killed four men from Skelani during the massacre of Srebrenica (HRW 1995). We see an element of possible revenge also in Model 2 where the coefficient for the lagged number of Bosniac victims is positively and significantly related to the number of Serbian victims. We will test the robustness of these relationships with VAR analyses reported below and in the Web appendix.

The military logic finds some support for the one-side violence perpetrated by the Bosniacs. While the number of Serbian victims increases with the number of battles, no relationship between the number of battles and the Bosnian victims exists. This confirms the third hypothesis partly, indicating that some, in particular the Serbian civilians, might fall victim to the intensity of the fighting. Controlling for combat intensity, we see in Table 1, column 3 that Bosniac military success does not shield its own civilians 
TABLE 1 Determinants of the Log-Transformed Weekly Number of One-Sided Violence Victims during the Bosnian Civil War

\begin{tabular}{|c|c|c|c|c|}
\hline & $\begin{array}{c}\text { Bosniac } \\
\text { victims of } \\
\text { Serbian OSV } \\
\text { (1) }\end{array}$ & $\begin{array}{c}\text { Serbian victims } \\
\text { of Bosniac } \\
\text { OSV } \\
\text { (2) }\end{array}$ & $\begin{array}{c}\text { Bosniac } \\
\text { victims of } \\
\text { Serbian OSV } \\
\text { (3) }\end{array}$ & $\begin{array}{c}\text { Serbian victims } \\
\text { of Bosniac } \\
\text { OSV } \\
\text { (4) }\end{array}$ \\
\hline $\begin{array}{c}\text { Log Serbian victims } \\
\text { of Bosniac OSV }\end{array}$ & $\begin{array}{l}0.255^{*} \\
(1.86)\end{array}$ & & & \\
\hline $\begin{array}{l}\text { Log Serbian victims } \\
\text { of Bosniac OSV } \\
t-1\end{array}$ & $\begin{array}{c}0.047 \\
(0.45)\end{array}$ & & & \\
\hline $\begin{array}{l}\text { Log Bosniac victims } \\
\text { of Serbian OSV }\end{array}$ & & $\begin{array}{l}0.117^{* * * *} \\
(2.75)\end{array}$ & & \\
\hline $\begin{array}{l}\text { Log Bosniac victims } \\
\text { of Serbian OSV } \\
t-1\end{array}$ & & $\begin{array}{l}0.070^{*} \\
(1.73)\end{array}$ & & \\
\hline Number of battles & & & $\begin{array}{r}0.086 \\
(0.75)\end{array}$ & $\begin{array}{l}0.265^{* * *} \\
(9.21)\end{array}$ \\
\hline Bosniac territorial wins & & & $\begin{array}{r}0.340 \\
(0.96)\end{array}$ & $\begin{array}{l}-0.226^{* * *} \\
(-2.60)\end{array}$ \\
\hline Bosniac territorial wins ${ }_{t-1}$ & & & $\begin{array}{r}0.060 \\
(0.26)\end{array}$ & $\begin{array}{l}0.196^{* *} \\
(2.41)\end{array}$ \\
\hline Serbian territorial wins & & & $\begin{array}{r}0.062 \\
(0.30)\end{array}$ & $\begin{array}{l}-0.271^{* * *} \\
(-3.55)\end{array}$ \\
\hline Serbian territorial wins ${ }_{t-1}$ & & & $\begin{array}{l}-0.182^{* *} \\
(-2.38)\end{array}$ & $\begin{array}{c}0.043 \\
(0.86)\end{array}$ \\
\hline Constant & $\begin{array}{l}2.410^{* * * *} \\
(6.19)\end{array}$ & & $\begin{array}{l}2.390^{m * * *} \\
(6.20)\end{array}$ & \\
\hline ARIMA model & $(1,0,1)$ & $(1,0,0)$ & $(1,0,1)$ & $(1,0,0)$ \\
\hline$\Phi_{1}(\operatorname{lag} 1)$ & $\begin{array}{l}0.879^{* * *} \\
(12.31)\end{array}$ & $\begin{array}{l}0.266^{* * *} \\
(4.77)\end{array}$ & $\begin{array}{l}0.874^{* * x} \\
(11.70)\end{array}$ & $\begin{array}{l}0.259^{* * *} \\
(4.95)\end{array}$ \\
\hline$\Theta_{1}(\operatorname{lag} 1)$ & $\begin{array}{l}-0.693^{* * * *} \\
(-6.67)\end{array}$ & & $\begin{array}{l}-0.683^{* * *} \\
(-6.27)\end{array}$ & \\
\hline Diagnostics & & & & \\
\hline $\mathrm{N}$ & 186 & 186 & 186 & 186 \\
\hline Loglikelihood & -397.634 & -297.958 & -392.728 & -291.839 \\
\hline AIC & 807.268 & 603.915 & 803.456 & 597.678 \\
\hline BIC & 826.622 & 616.818 & 832.488 & 620.258 \\
\hline
\end{tabular}

Note: The results were obtained with STATA 11. All outcome variables are log-transformed, missing values resulting from this equalised to zero, t-ratios are in parentheses. OSV $=$ one-sided violence.

${ }^{*} p<.1,{ }^{* *} p<.05,{ }^{* * *} p<.01$.

sufficiently against Serbian assaults. The variable controlling for territorial gains by the Serbs is not significantly related to the number of Bosnian victims in the same week, and has a highly significant, negative coefficient if lagged by one week. The influence of the past Serbian conquests on one-sided violence perpetrated by Serbs indicates that the direct killings decreased after military operations. We attribute this drop, which supports our hypothesis, to two tendencies in the Serbian victimization of the Muslim population. First, the Serbs detained many Bosniacs in camps after their victories (Kalyvas and Sambanis 2005:13). The human rights violations committed there do not appear in our one-sided violence figures as the camp 
violence most often cannot be attributed to a specific date. Further, the Serbs relied heavily on indiscriminate artillery shelling when they attacked territory held by the Bosniacs (Kaser 2007:410; see also Gow 2007, ICTY 2009) and drove civilians out of their home directly during this military campaign (Stover 2005). Additionally, the coding of the data from news accounts could be responsible for this drop in civilian victimization, if one presumes that reports from newly conquered territories were scarce.

A growing number of territorial conquests by the Bosniacs lowers the risk of one-sided violence in the contemporary week for the Serbian victims, but increases it in the subsequent period. This indicates that this weaker group did not resort to one-sided violence while it was militarily successful. However, civilian victimization increased after territorial conquests. The results in Table 1, column 4 also demonstrate that the Serbian civilians seem to have been safer if the Serbs were militarily advancing.

Table 2 examines the incidence of one-sided violence through the perspective of the international interventions. We show that the lagged indicators of UN and NATO activities do not necessarily reduce civilian suffering. While UN resolutions calling for increases in peacekeeping troops reduce the weekly number of one-sided violence by the Serbs, no such influence on the Bosniac behavior is visible. None of the remaining UN variables are significantly correlated with the level of violence. These results suggest that the impact of international interventions remained very limited. Models 3 and 4, which study the impact of agreements between various international actors and the warring parties, similarly demonstrate the problems of international involvement. While a rapprochement between Russia and the Serbs reduces the number of people killed or harmed by this group, increased cooperation between the United Nations and the Serbs is linked to a growing number of victims of Serbian violence. However, the moderating influence of RussianSerb agreements on the extent of one-sided violence is the only robust relationship we find regarding international interventions. Surprisingly, an agreement between the Bosniac side and the United States is related to more Bosniac atrocities. This finding appears to stem from the fact that these agreements clustered in the final weeks of the conflict, when the US-led NATO operation "Deliberate Force" began to bombard Bosnian Serb positions and Bosniac and Croat forces advanced on the ground.

The results reported in Tables 1 and 2 identify some of the key correlates of one-sided violence during the Bosnian civil war. We used VAR models to establish whether some of the associations identified are Grangercaused by the main variables of interest. Additional results reported in the Web appendix confirm that agreement between the United States and the Bosniacs is related to more one-sided violence committed by the Bosniacs. The Serbs, by contrast, were only systematically influenced by changes in the agreements between Russia and Serbia. Similar to the analysis of Goldstein 
TABLE 2 Determinants of the Log-Transformed Weekly Number of One-Sided Violence Victims during the Bosnian Civil War

\begin{tabular}{|c|c|c|c|c|}
\hline & $\begin{array}{l}\text { Bosniac victims } \\
\text { of Serbian OSV } \\
\text { (1) }\end{array}$ & $\begin{array}{l}\text { Serbian victims } \\
\text { of Bosniac OSV } \\
\text { (2) }\end{array}$ & $\begin{array}{l}\text { Bosniac victims } \\
\text { of Serbian OSV } \\
\text { (3) }\end{array}$ & $\begin{array}{l}\text { Serbian victims } \\
\text { of Bosniac OSV } \\
\text { (4) }\end{array}$ \\
\hline NATO attack ${ }_{t-1}$ & $\begin{array}{l}0.762 \\
(0.91)\end{array}$ & $\begin{array}{l}-0.424 \\
(-0.60)\end{array}$ & & \\
\hline UN sanctions ${ }_{t-1}$ & $\begin{array}{l}-1.020 \\
(-1.02)\end{array}$ & $\begin{array}{l}-0.590 \\
(-0.91)\end{array}$ & & \\
\hline UN condemnation ${ }_{t-1}$ & $\begin{array}{r}0.187 \\
(0.39)\end{array}$ & $\begin{array}{r}0.145 \\
(0.33)\end{array}$ & & \\
\hline UN tribunal ${ }_{t-1}$ & $\begin{array}{l}1.398 \\
(1.61)\end{array}$ & $\begin{array}{r}0.307 \\
(0.53)\end{array}$ & & \\
\hline UNPROFOR $_{t-1}$ & $\begin{array}{l}-0.699^{*} \\
(-1.74)\end{array}$ & $\begin{array}{l}-0.316 \\
(-1.28)\end{array}$ & & \\
\hline $\begin{array}{l}\text { Agreement } \\
\text { U.S.A.-Serbs }\end{array}$ & & & $\begin{array}{l}-0.350 \\
(-0.47)\end{array}$ & $\begin{array}{r}0.581 \\
(1.32)\end{array}$ \\
\hline Agreement EU-Serbs & & & $\begin{array}{l}-0.660 \\
(-0.95)\end{array}$ & $\begin{array}{c}0.137 \\
(0.33)\end{array}$ \\
\hline Agreement UN-Serbs & & & $\begin{array}{c}0.752^{*} \\
(1.92)\end{array}$ & $\begin{array}{l}0.308 \\
(1.43)\end{array}$ \\
\hline $\begin{array}{l}\text { Agreement } \\
\text { Russia-Serbs }\end{array}$ & & & $\begin{array}{l}-1.420^{*} \\
(-1.76)\end{array}$ & $\begin{array}{l}-0.689 \\
(-0.79)\end{array}$ \\
\hline $\begin{array}{l}\text { Agreement } \\
\text { USA-Bosniacs }\end{array}$ & & & $\begin{array}{l}0.134 \\
(0.26)\end{array}$ & $\begin{array}{l}0.930^{* * *} \\
(2.41)\end{array}$ \\
\hline $\begin{array}{l}\text { Agreement } \\
\text { EU-Bosniacs }\end{array}$ & & & $\begin{array}{r}0.313 \\
(0.58)\end{array}$ & $\begin{array}{l}0.095 \\
(0.24)\end{array}$ \\
\hline $\begin{array}{l}\text { Agreement } \\
\text { UN-Bosniacs }\end{array}$ & & & $\begin{array}{l}-0.135 \\
(-0.35)\end{array}$ & $\begin{array}{l}-0.363 \\
(-1.33)\end{array}$ \\
\hline $\begin{array}{l}\text { Agreement } \\
\text { Russia-Bosniacs }\end{array}$ & & & $\begin{array}{l}-0.159 \\
(-0.24)\end{array}$ & $\begin{array}{c}0.038 \\
(0.07)\end{array}$ \\
\hline Constant & $\begin{array}{l}2.580^{* * * *} \\
(5.71)\end{array}$ & & $\begin{array}{l}2.495^{* * *} \\
(5.38)\end{array}$ & \\
\hline $\begin{array}{l}\text { ARIMA } \\
\qquad \Phi_{1}(\operatorname{lag} 1) \\
\Phi_{4}(\operatorname{lag} 4)\end{array}$ & $\begin{array}{l}(1,0,1) \\
0.887^{* * * *} \\
(14.48)\end{array}$ & $\begin{array}{c}(1,0,1)(1,0,0)_{12} \\
0.911^{* * * *} \\
(19.54)\end{array}$ & $\begin{array}{l}(1,0,1) \\
0.890^{* * * *} \\
(13.66)\end{array}$ & $\begin{array}{l}(4,0,0) \\
0.358^{* * * *} \\
(7.67) \\
0.236^{* * * *} \\
(3.73)\end{array}$ \\
\hline $\begin{array}{l}\Theta_{1}(\operatorname{lag} 1) \\
\Phi_{1,12}\end{array}$ & $\begin{array}{l}-0.652^{* * *} \\
(-6.91)\end{array}$ & $\begin{array}{c}-0.674^{* * * *} \\
(-8.86) \\
0.142^{* *} \\
(2.21)\end{array}$ & $\begin{array}{l}-0.665^{* * *} \\
(-6.52)\end{array}$ & \\
\hline \multicolumn{5}{|l|}{ Diagnostics } \\
\hline $\begin{array}{l}\mathrm{N} \\
\text { Loglikelihood } \\
\text { AIC } \\
\text { BIC }\end{array}$ & $\begin{array}{r}186 \\
-395.445 \\
808.889 \\
837.921\end{array}$ & $\begin{array}{r}186 \\
-295.837 \\
609.674 \\
638.706\end{array}$ & $\begin{array}{r}187 \\
-397.198 \\
818.395 \\
857.169\end{array}$ & $\begin{array}{r}187 \\
-295.030 \\
612.060 \\
647.602\end{array}$ \\
\hline
\end{tabular}

Note: The results were obtained with STATA 11. All outcome variables are log-transformed, missing values resulting from this equalised to zero, t-ratios are in parentheses. OSV $=$ one-sided violence. ${ }^{*} p<.1,{ }^{* *} p<.05,{ }^{* * *} p<.01$.

and Pevehouse (1997), outside actors have thus at least partly shaped the campaigns of an ally.

Table 3 reports the Granger causality tests for the interrelationships between the (endogenous) variables associated with the usage of political 
TABLE 3 Granger Causality Tests of Key Correlates of the Bosnian Civil War

\begin{tabular}{|c|c|c|c|c|c|}
\hline & $\begin{array}{l}\text { Bosniac victims } \\
\text { of Serbian OSV }\end{array}$ & $\begin{array}{l}\text { Serbian victims } \\
\text { of Bosniac OSV }\end{array}$ & $\begin{array}{l}\text { Number } \\
\text { of battles }\end{array}$ & $\begin{array}{l}\text { Bosniac } \\
\text { territorial } \\
\text { wins }\end{array}$ & $\begin{array}{c}\text { Serbian } \\
\text { territoria } \\
\text { wins }\end{array}$ \\
\hline $\begin{array}{l}\text { Bosniac OSV } \\
\text { victims }\end{array}$ & & $8.8329^{*}$ & 4.9549 & 2.4231 & 6.2539 \\
\hline $\begin{array}{l}\text { Serbian OSV } \\
\text { victims }\end{array}$ & $10.443^{\text {*** }}$ & & $12.193^{* *}$ & $29.218^{* * *}$ & $10.493^{* *}$ \\
\hline $\begin{array}{l}\text { Number of } \\
\text { battles }\end{array}$ & 2.5851 & $15.347^{* * *}$ & & 4.3574 & 2.517 \\
\hline $\begin{array}{l}\text { Bosniac } \\
\text { territorial } \\
\text { wins }\end{array}$ & $11.372^{* *}$ & 3.834 & 5.549 & & 5.05 \\
\hline $\begin{array}{l}\text { Serbian } \\
\text { territorial } \\
\text { wins }\end{array}$ & 7.2494 & $8.1047^{*}$ & 3.0875 & 1.9175 & \\
\hline All & $29.817^{* * *}$ & $44.404^{* * * *}$ & $34.498^{* * *}$ & $56.714^{* * *}$ & 21.841 \\
\hline
\end{tabular}

Note: OSV $=$ one-sided violence. $\operatorname{VAR}(4)$, entries are $\chi^{2}$-statistics, ${ }^{*} p<.1,{ }^{* *} p<.05,{ }^{* * *} p<.01$.
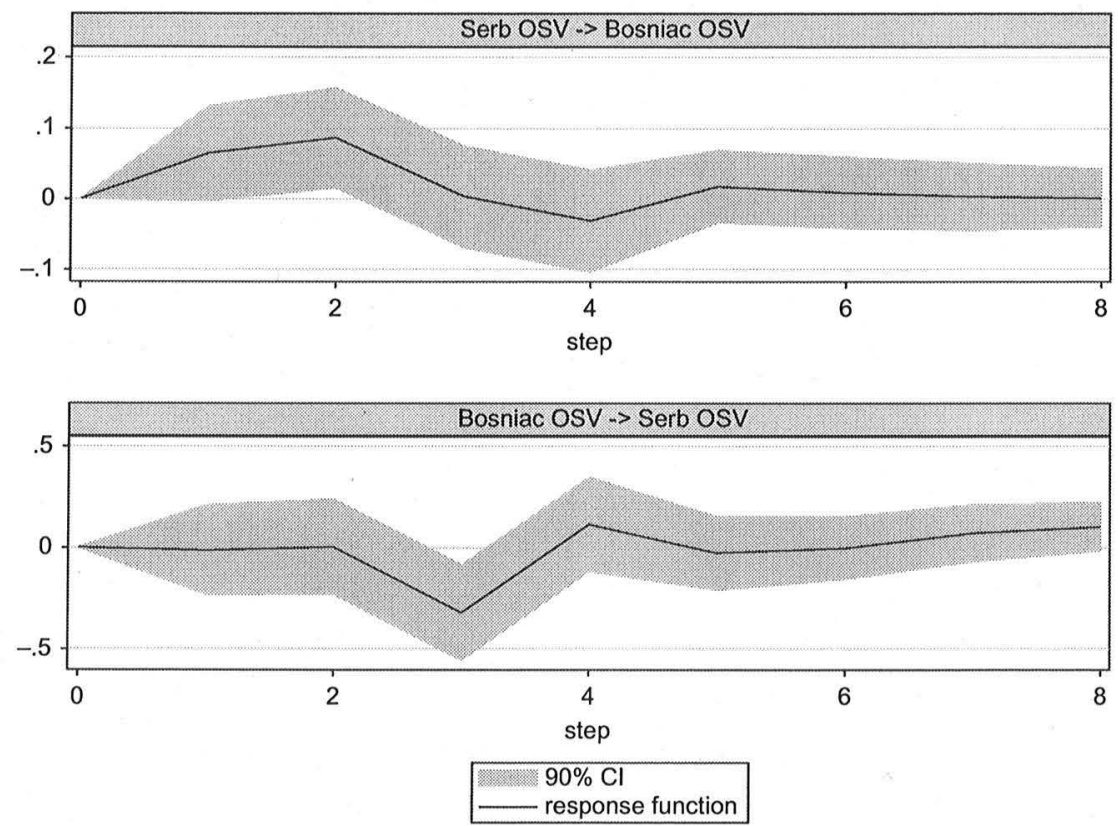

FIGURE 2 Impulse-response functions for the reciprocity model with Serbian and Bosniac one-sided violence as endogenous variables.

violence. The analysis lends support to the massacre logic as changes in the usage of one-sided violence by the Serbs provoke subsequent civilian victimisation by the Bosniacs. Figure 2 illustrates this finding. While the impact of Serbian violence on Bosniac civilian victimization differs from zero, this is not systematically the case in the lower figure, which plots the 
impulse response function for the opposite relationship. ${ }^{6}$ The VAR analysis also supports the finding of retaliation on the part of the Bosniac perpetrators. Moreover, Serbian battle success is not related to the subsequent number of Bosniac victims; this suggests that the militarily stronger side had the victimisation of civilians subjugated to the military campaign. However, if the Bosniacs won territory in the previous weeks, they had to count with more violence directed against their civilians. The double finding that Serb violence seems largely driven by autocorrelation and appears to be exogenous to the model corresponds, in our view, with the observation that the Serbian strategy of ethnic cleansing was deliberate and centrally planned in advance (Gow 2007; Kaser 2007).

\section{CONCLUSION}

Recent research strongly suggests that strategic calculations account for many instances of one-sided violence. Distinguishing among military developments, retaliation and international interventions, we have added a dynamic analysis to this emerging literature. The article particularly shows for the Bosnian civil war, in line with the military logic, that the developments on the battleground influence the victimization of civilians. While some onesided violence is part of the overall military strategy or has to be seen partly as collateral damage, other events in this war are retaliatory acts. Our analysis also evinces that international interventions often remain ineffective.

Our dynamic perspective allows us to show that Serbs and Bosniacs did not only rely on one-sided violence to a highly dissimilar degree, but that they also employed this instrument differently in comparable contexts. The Muslim side increased its violence after a territorial conquest, while the Serbs decreased it in the weeks after geographical expansion. This sheds some light on the question of whether or not the militarily weak or strong rely on onesided violence. According to our analysis, the two sides either employed it according to an overall strategic plan (the Serbs) or relied on it when they had the resources to do so (the Bosniacs). International interventions appear to have exerted a very limited influence on the level of violence, indicating that preventive action should have been pursued more rigorously. Admittedly, the bombing of the Serbs after Srebrenica ended the conflict. However, the ineffectiveness of the other measures indicates that third party interventions in the form of resolutions and sanctions are often not sufficient to reduce the extent of civilian victimization once the political and military leaders have put their devilish plans into motion.

\footnotetext{
${ }^{6}$ These influences remain similar across different lag specifications, but confidence intervals widen in some cases. We report the finding with a lag of 4 which is in line with our theoretical expectation of considerable autocorrelation.
} 


\section{REFERENCES}

Brunborg, Helge, Torkil Hovde Lyngstad, and H. Henrik Urdal. (2003) Accounting for Genocide: How Many Were Killed in Srebrenica? European Journal of Population 19(3):229-248.

Burg, Steven L., and Paul S. Shoup. (1999) The War in Bosnia-Herzegovina. Armonk, NY: M.E. Sharpe.

Crescenzi, Mark J. C. (2007) Reputation and Interstate Conflict. American Journal of Political Science 51(2):382-396.

Dinter, Vanessa. (2008) Strategic Logic of One-Sided Violence in Civil Wars. The Case of Bosnia and Herzegovnia. Diploma Thesis, University of Konstanz.

Downes, Alexander B. (2008). Targeting Civilians in War. Ithaca: Cornell University Press.

Eck, Kristine, and Lisa Hultman. (2007) One-Sided Violence Against Civilians in War: Insights from New Fatality Data. Journal of Peace Research 44(2):233-246.

Forsythe, David P. (2005). The Humanitarians: The International Committee of the Red Cross. Cambridge: Cambridge University Press.

Goldstein, Joshua S., and Jon C. Pevehouse. (1997) Reciprocity, Bullying, and International Cooperation: A Time-Series Analysis of the Bosnia Conflict. The American Political Science Review 91(3):515-529.

Gow, James. (2007) Strategien und Kriegsziele [Strategies and War Aims]. In Der Jugoslawien-Krieg: Handbuch zu Vorgeschichte, Verlauf und Konsequenzen [The Yugoslavia War: Handbook of Prehistory, Progression and Consequences], edited by Dunja Melcic. Wiesbaden: VS Verlag für Sozialwissenschaften, pp. 362-378.

Grossman, Dave. (1995) On Killing: The Psychological Cost of Learning to Kill in War and Society. Boston: Little, Brown \& Co.

Hegre Håvard, and Nicholas Sambanis. (2006) Sensitivity Analysis of the Empirical Literature on Civil War Onset. Journal of Conflict Resolution 50(4): 508-535.

Herreros, Francisco, and Henar Criado. (2009) Pre-Emptive or Arbitrary. Two Forms of Lethal Violence in a Civil War. Journal of Conflict Resolution 53(3):419-45.

Hultman, Lisa. (2009) The Power to Hurt in Civil War: The Strategic Aim of RENAMO Violence. Journal of South African Studies 35(4):821-834.

Human Rights Watch. (1995) The Fall of Srebrenica and the Failure of UN Peacekeeping. Available at http://www.hrw.org/en/node/85087/section/15.

International Criminal Court for the Former Yugoslavia. (2002) Amended Indictment "Bosnia and Herzegovina." Available at http://www.icty.org/x/cases/ slobodan_milosevic/ind/en/mil-ai040421-e.htm

International Criminal Court for the Former Yugoslavia. (2009) Third Amended Indictment. Available at http://www.icty.org/x/cases/karadzic/ind/en/090227. pdf

International Criminal Tribunal of the Former Yugoslavia. (2006) International Tribunal for the Prosecution of Persons Responsible for Serious Violations of International Humanitarian Law Committed in the Territory of Former Yugoslavia since 1991. Available at http://www.icty.org/x/cases/oric/tjug/en/ orijud060630e.pdf 
Kalyvas, Stathis N. (1999) Wanton and Senseless? The Logic of Massacre in Algeria. Rationality and Society 11(3):243-285.

Kalyvas, Stathis N. (2006) The Logic of Violence in Civil War. Cambridge: Cambridge University Press.

Kalyvas, Stathis N., and Nicholas Sambanis. (2005) Bosnia's Civil War: Origins and Violence Dynamics. In Understanding Civil War: Evidence and Analysis, edited by Paul Collier and Nicholas Sambanis. Washington, DC: The World Bank, pp. 191-230.

Kaser, Karl. (2007) Das Ethnische "Engineering" [The Ethnic 'Enineering']. In Der Jugoslawien-Krieg: Handbuch zu Vorgeschichte, Verlauf und Konsequenzen [The Yugoslavia War: Handbook of Prehistory, Progression and Consequences], edited by Dunja Melcic. Wiesbaden: VS Verlag für Sozialwissenschaften, pp. 401-414.

Kuper, Leo. (1982) Genocide: Its Political Use in the Twentieth Century. New Haven: Yale University Press,

Krain, Matthew. (2005) International Intervention and the Severity of Genocides and Politicides. International Studies Quarterly 49(3):363-387.

Kramer, Alan. (2007) Dynamic of Destruction. Culture and Mass Killing in the First World War. Oxford: Oxford University Press.

Longerich, Peter. (1998) Die Wannsee-Konferenz vom 20. Januar 1942. Planung und Beginn des Genozids an den europäischen Juden [The Wannsee Conference of January 20, 1942. Planning and Beginning of the Genocide of the European Jews]. Berlin: Edition Hentrich.

Meernik, James. (2005) Justice and Peace? How the International Criminal Tribunal Affects Societal Peace in Bosnia. Journal of Peace Research 42(3):271-289.

Morrow, James D. (2007) When Do States Follow the Laws of War? American Political Science Review 101(3):559-572.

Oberschall, Anthony. (2000) The Manipulation of Ethnicity: From Ethnic Cooperation to Violence and War in Yugoslavia. Ethnic and Racial Studies 23(6):982-1001.

Obermeyer, Ziad, Christopher J. L. Murray, and Emmanuela Gakidou. (2008) Fifty Years of Violent War Deaths from Vietnam to Bosnia: Analysis of Data from the World Health Survey Programme. British Medical Journal 336(73333):1482-1486.

Powell, Robert. (2002) Bargaining Theory and International Conflict. Annual Review of Political Science 5:1-30.

Raleigh, Clionadh, Andrew Linke, Håvard Hegre, and Joachim Carlsen. (2010) Introducing ACLED: An Armed Conflict Location and Event Dataset. Journal of Peace Research 47(5):651-660.

Rummel, Rudolph J. (1994) Power, Genocide, and Mass Murder. Journal of Peace Research 31(1):1-10.

Schneider, Gerald, Thomas Widmer, and Dieter Ruloff. (1993) Personality, Unilateralism, or Bullying: What Caused the End of the Cold War? International Interactions 18(4):323-342.

Schneider, Gerald, Lilli Banholzer, and Roos Haer. (2011) Cain's Choice: Causes of One-Sided Violence Against Civilians. In Causes of War: An Introduction to Theories Behind Warfare and Collective Violence, edited by Tor Georg Jakobsen. New York: Nova Science Publishers, pp. 57-82. 
Schneider, Gerald, and Margit Bussmann. (2012) Accounting for the Dynamics of One-Sided Violence: Introducing KOSVED, Working paper, Universität Konstanz/Universität Greifswald.

Spagat, Michael, Andrew, Mack, Tara Cooper, and Joakim Kreutz. (2009) Estimating War Deaths: An Arena of Contestation. Journal of Conflict Resolution 53(6):934-950.

Stover, Eric. (2005) The Witnesses. War Crimes and the Promise of Justice in The Hague. Philadelphia: University of Pennsylvania Press.

Tabeau, Ewa, and Jakub Bijak. (2005) War-Related Deaths in the 1992-1995 Armed Conflicts in Bosnia and Herzegovina: A Critique of Previous Estimates and Recent Results. European Journal of Population 21(2/3):187-215.

Valentino, Benjamin A., Paul Huth, and Dylan Balch-Lindsay. (2004) "Draining the Sea": Mass Killing and Guerilla Warfare. International Organization 58(2):375-407.

Weidmann, Nils B. (2011) Violence "from above" or "from below"? The Role of Ethnicity in Bosnia's Civil War. Journal of Politics 73(4):1178-1190.

Wood, Elizabeth J. (2006) Variation in Sexual Violence During War. Politics and Society 34(3):307-341. 